\title{
The potential role of Monsoon-induced humidity in India's unexpected Covid-19 case decline and subsequent rise considering seasonality
}

\author{
Virendra Mane * and Poorva Bhalerao \\ QualEx Systems Private Limited, Pune, India \\ *. Corresponding author: Virendra Mane, QualEx Systems Private Limited, Pune, India. \\ Phone: +91-94220-89321. E-mail: Virendra_mane@qualexsystems.com.
}

Cite this article: Mane, V., Bhalerao, P. The potential role of Monsoon-induced humidity in India's unexpected Covid-19 case decline and subsequent rise considering seasonality. Int J Epidemiol Health Sci 2021;2(7):e15. Doi: 10/51757/IJEHS.2.7.2021.244388.

\begin{abstract}
Background: The COVID-19 pandemic was expected to affect India severely; cases rose exponentially from MayJune 2020, but around mid-September reached their peak and started declining. It showed a sign of the wave's completion by the end of January 2021. This decline was not predicted by any models and the authors have not come across any explanation. Winter seasonality of influenza and similar viruses is well known and observed fact and that it has a direct correlation to the colder temperatures as well as lower humidity. Similarly, in low humidity, viruses are most viable, and they become ineffective as the humidity increases and reaches its maximum extent. This article hypothesizes and tries to explain the cause behind the first major decline and shows the subsequent rise of the second wave, and one short low humidity period followed by a high humidity period between the first and second waves.

Methods: The humidity cycles in India were studied to find high and low relative humidity periods, which then corresponded to the daily cases in the country (macro-level), region (mid-level), and smaller regions (micro-level).

Results: A definite correlation was observed between Monsoon-induced humidity and the incidence rate decline. This happens in 8 to 10 weeks. Incidence rates start declining about 4 weeks after the peak humidity is reached in a particular region. A decrease in humidity below $65 \%$ or $55 \%$ or lower causes an increase in the case increase/uptrend in about 3-4 weeks.

Conclusion: COVID-19 has a seasonal peak in India, peaking in the middle of the monsoon season around midSeptember and reaching its lowest levels in January-February. As humidity drops from February to June/July, a trend reversal and sharp rise are expected. The subsequent wave/case peak would be expected to be seen around midSeptember 2021.
\end{abstract}

Keywords: Epidemiology, Public Health, Infectious Diseases, SARS-COV2, Covid-19, Monsoon, India 


\section{Introduction}

The COVID-19 pandemic was expected to affect India severely. The primary reasons are that it is i) the world's second most populous country after China (1), ii) a high population density of 464 per square $\mathrm{km}$, ranking second only to Bangladesh among the top 15 countries with populations of 100 million or more (1), and iii) an inadequate public health infrastructure (2).

India imposed a strict and complete nationwide lock down on 24th March 2020. The initial lockdown was announced for a 3-week period and was further extended until the end of May 2020 (2). The extension resulted in a sudden labor migration away from the hotspots and back to their rural homes. Cases began to increase nationwide in June $2020(3,4)$, owing in part to labor migration and subsequent relaxation following the lockdown.

While it was assumed India would cross the USA in total cases sometime in September 2020, suddenly and inexplicably, the new daily cases started declining around mid-September after reaching the maximum daily cases of 97,894 on 17 -September2020 (Figure 1). By January 2021, Covid-19 showed a sign of reaching the bottom, with daily cases reaching 8,579 on 2-Feb-2021 (Figure 1), a proper wave completion as usually seen in such pandemics.

It is a well-known fact that a decline in temperature and humidity increases the occurrence of influenza in temperate climate zones $(5,6)$. It is also known that viruses containing aerosols evaporate faster and stay airborne longer in dry/low humidity climates, reducing the occurrence of influenza (7), and that the virus has a high viability below $50 \%$ relative humidity (8). Recent Covid-19 specific studies show the effects of environmental factors, with humidity being one of the most important factors, affecting Covid-19 and causing seasonality $(9,10)$. And it has been observed that enveloped viruses, which contain a lipid membrane, survive better at lower Relative Humidity (RH) (11). It has been seen that the rehydration, due to higher humidity, of enveloped viruses affects their viability $(12,13)$.

This article hypothesizes and tries to explain the cause of monsoon-induced humidity behind the decline in India and shows how the start of the driest/least-humidity periods correlates to another subsequent rise in cases (the Second Wave of India in 2021), while establishing the seasonality of Covid-19 in India.

\section{Materials and methods}

An Observational Study approach was used for this, and the method used is to observe the daily Mean Relative Humidity (RH) in India and compare and corelate it with the reported daily Covid-19 Cases via Descriptive Statistical Analysis. The Monsoon season, which lasts about 4 months from June to October (14), and a phenomenon called as "Western Disturbances" which brings post-monsoon and winter rains and humidity in the Northern and North Western regions of the country from October to January (15), are the major and distinguishing cause of increased humidity in most of the country.

Later, the study was extended to identify the low humidity period and establish a correlation with the subsequent rise, including the most important Second Wave of India in 2021. Monsoon (South-West monsoon) progression observations for humidity were made at Macro, Mid and Micro levels as follows:

\section{Macro Level - Country:}

The entire country-specific Covid-19 case data for the period 15-March-2020 to 20-April2021 is being considered for this study. This is a crude/macro-level observation as India is a large country and the monsoon rain and humidity reach different locations at different times. It is not possible to have a single country-wide curve/number for humidity, hence an approximation of the time when the monsoon envelopes the entire country is used.

\section{Mid-Level - Region Bands:}

The monsoon follows a path from states on the southern peninsula to states in the North and the North-West in a set pattern. Rainfalls and humidity levels rise at roughly the same rate in these areas. This progression spans an area covering multiple states. These states are clubbed together into five regional bands as per the Indian Meteorological Department (IMD)'s monsoon progression details (Figure 2). Band A (Blue) has the earliest onset and longest duration of the monsoon, while Band E (Orange) has the latest and shortest. Bands A and B are subdivided into two, to account for the impact of the North-East monsoon on the Southeastern states. Band A.2 and Band B. 2 received more rain in the October to December period. The Covid-19 daily case data and humidity of representative locations (weather stations) for humidity data are observed. These five bands are being investigated for the period 15-March-2020 to 20-April-2021, ranging from 
the earliest and longest monsoon durations to the latest and shortest.

\section{Micro Level - Smaller Locations:}

For even more accurate observations, a local administrative unit of a 'district', which has similar humidity and Covid-19 case data available, is being studied. Twenty-Six (26) districts, mostly containing major hotspots in the country, are studied to get specific and accurate regional climatic, i.e., Relative Humidity data and corresponding effect on cases. This is a micro-level analysis that provides a more accurate and immediate reflection of humidity and other interventions (local lockdowns, restrictions, and so on) on a daily basis. This study of smaller locations gives observations of local declines and rises which happen at different time periods. The Relative Humidity data used for this research is for the period 1-January-2020 to 9-April-2021 and Covid-19 daily case data is from 26-April2020 to 9-April-2021.

The monsoon entered India from the southernmost tip on $1^{\text {st }}$ June 2020 and covered the entire country by $8^{\text {th }}$ July, as official Indian Meteorological Department information (14). The path traversed is as shown in Figure 2. The monsoon started withdrawing around $28^{\text {th }}-29^{\text {th }}$ September 2020 and took a similar path during the reversal, while it officially ended and exited the country on $28^{\text {th }}-30^{\text {th }}$ October as per the Indian Meteorological Department (16). The southern states of Tamil Nadu and Kerala have an extended rainy period due to the North-East Monsoon, which is from October to December (17). In this study, a relatively lower relative humidity period was witnessed almost all over the country from around $1^{\text {st }}$ to $14^{\text {th }}$ November (Figure 1). This was followed by increased humidity from $18^{\text {th }}$ November, due primarily to unseasonal rain events mostly caused by two Cyclones (Hurricanes) developed in the Bay of Bengal and their aftereffects, namely a) Cyclone Nivar ( $23^{\text {rd }}$ to $27^{\text {th }}$ November) as per the press release by the India Meteorological Department (18) and b) Cyclone Burevi ( $1^{\text {st }}$ to $5^{\text {th }}$ December) as per the press release by the India Meteorological Department (19). The second cyclone Burevi crossed over from over southern India towards Arabian sea and kept on bringing in substantial humidity and/or rains over a large area of the country, till around $15^{\text {th }}$ to $20^{\text {th }}$ December. NorthWestern states witness a phenomenon called the "Western Disturbance" which brings rain and increased relative humidity_during the winter months of October to December (15).

\section{Data Sources}

The Relative Humidity data has been collected from Reliable Prognosis, Raspisaniye Pogodi Ltd., St. Petersburg, Russia, since 2004, published and downloadable online from https://rp5.ru.

The Daily Covid-19 case data was collected from covid19india.org, which fetches data using state bulletins and official handles. The data is validated by a group of volunteers and published on a Google sheet and on an API. The following data files were used for this study:

i) National and State level https://api.covid19india.org/csv/latest /state wise daily.csv

ii)

\begin{tabular}{l}
$\begin{array}{l}\text { District level } \\
\text { https://api.covid19india.org/csv/latest }\end{array}$ \\
\hline /districts.csv
\end{tabular}

The main data sources can be accessed from:

1. India Coronavirus Pandemic Data: https://www.covid19india.org/

2. Relative Humidity Data: https://rp5.ru/Weather_in_the_world

3. Weather Data

a. Indian Meteorological Department: https://mausam.imd.gov.in/

b. Western Disturbances https://en.wikipedia.org/wiki/Weste rn_Disturbance

c. Western Disturbances - Detailed https://empowerias.com/blog/dailyarticles/western-disturbances-andits-impact-on-the-indiansubcontinent-gs:-3-empower-ias 


\section{India: Covid-19 Daily Cases - 7 Day Moving Average Daily Cases}

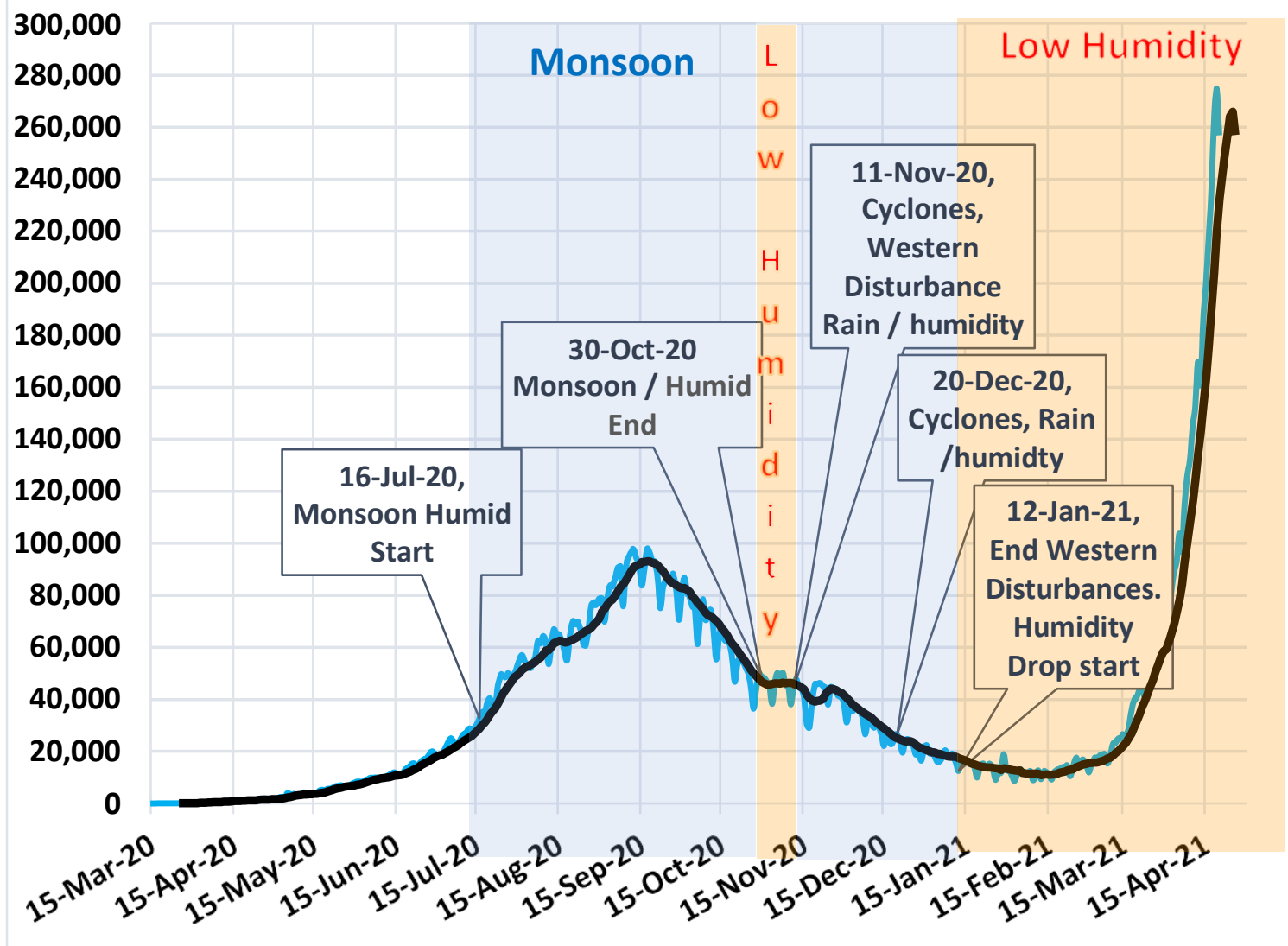

Figure 1. India's daily cases (Country/Macro)-Level

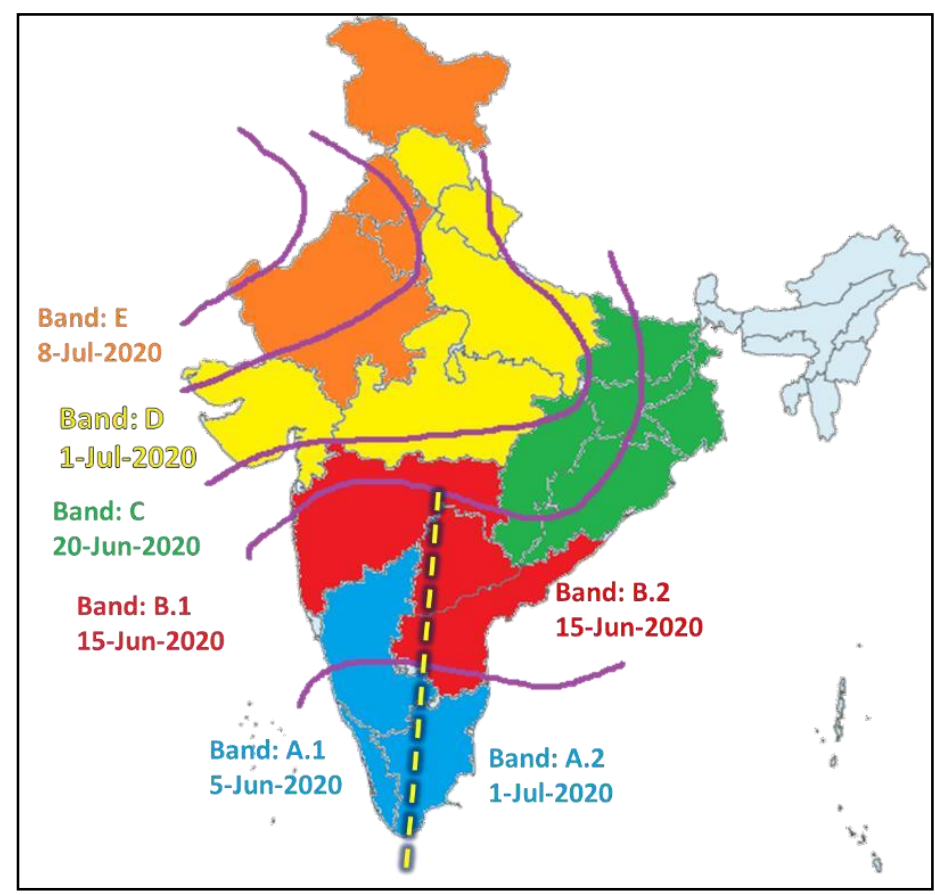

Figure 2. India's Monsoon bands 


\section{Results}

The study results are displayed on charts for each level: Macro, Mid and Micro:

\section{Macro - Country level}

After the full onset of the monsoon, the daily cases start declining around 8 weeks from the start of the peak humid period of $>90 \%$ (Figure 1). After the South-West Monsoon was over and exited the country

by October-end and a short rain-free low humidity period started, the daily cases showed a corresponding short increase, which is evident from an uptick/rise in daily cases between $16^{\text {th }}$ to $26^{\text {th }}$ November, i.e., about three weeks from the start of the low humidity period.

As previously stated, the period from

November $11^{\text {th }}$ to the end-December/mid-January2021 period showed a significant increase in humidity due to two cyclones in the mid-to-southern states and

the Western Disturbance rains/humidity in the

northern states. The daily case decline continued downward and dropped to around 9,000 by lateJan/early-Feb-2021.

\section{Regional (Mid-level) bands}

Regional bands are based on monsoon traversal and withdrawal paths (Figure 2). Band A (Blue) has the earliest and longest monsoon duration, while Band E (Orange) has the latest and shortest. To consider the effect of the North-East monsoon on the Southeastern states, bands A and B are subdivided into two bands. Band A.2 and band B.2 receive more rain in the October to December period.

The Covid-19 Daily New Cases number is plotted on a time series that shows a decrease in cases after the onset of the monsoon and the relative humidity of that region increases/reaches the maximum possible value for that region; an increase in cases is observed when the humidity drops significantly to the most viable conditions for the virus. On the time series chart, the following are used for easier visual understanding of monsoon entry and exit:

- Bright green vertical dashed lines show the monsoon reaching a particular band,

- Purple vertical dashed lines show the complete withdrawal from that band,

- The red vertical dashed lines indicate the approximate time when the humidity drops below $70 \%$ and continues to fall.

The onset and withdrawal of the monsoon is marked based on the dates published by the Indian Meteorological department. The approximate day for the drop in humidity is fetched from the micro-level data for districts in those bands:

\section{i) Band A}

This band is divided into two zones: Band A.1 includes the Western states (Karnataka, Kerala) and Band B.2 includes the Eastern states (Tamilnadu), which have different Monsoon timings and are significantly more humid. The case decline start date is much farther than South-West monsoon arrival, as some states in this band receive more rains in the withdrawal phase than during the start. It is worth noting that the case trend stabilizes in the second and third weeks of November, following the arrival of North-East monsoon, when humidity reaches its peak (Figure 3).

The South-West period in this band is 1-June2020 to 31-Oct-2020, but it experiences extended rains due to the North-East Monsoon, which ends around 20-Dec-2020. In band A.1, the relative humidity drops below $70 \%$ and lower around early-February and a slow increase is observed in early April. However, this needs to be studied in smaller regions, as the cases have been high and range-bound, forming a base of around 5,000 daily since late November 2020. There are a variety of other causes, other than climate, behind the increase, especially in the state of Kerala (e.g., relaxation of tourism, a substantial population returning from Middle Eastern countries and many people having jobs in the nursing/health-care segment), which need to be studied further.

In the Eastern states (A.2) in this band, the South-West Monsoon arrives on 1-July-2020. The humidity gradually increases to a narrow band of $80 \%$ to $90 \%$. This seems to have a stabilizing effect on the daily cases, neither increasing nor decreasing, but a decline is seen after the peak humidity in this band is reached. After the North-East Monsoon is over by 20Dec-2020, the relative humidity drops below $70 \%$ and lower around early-March 2021 and is followed by an increase in the number of cases around early April (Figure 4).

\section{ii) Band B}

The period of South-West Monsoon is 15June-2020 to 31-Oct-2020 for this. This band is divided into two zones. Band B.1 includes the western states (most notably Maharashtra, which is a significantly dry and low-humidity state). Band B.2 includes the eastern states of Andhra Pradesh and Telangana, which are significantly more humid (observed in the specific districts in these bands in the Micro-Level study in the next section). It is to be noticed that this band has a relatively low humidity period in the late-October to early-November period, followed by a small increase/uptick in the daily case trend, but stabilizes immediately by the second and 
third weeks of November as the humidity rises again. Around mid-January the humidity in band

B.1 drops below $70 \%$ and lower causing significantly rapid case increase by mid-February. One probable cause for the rapid increase in band B.1 could be a relatively high daily case incidence at the bottom of the range of around 3,000-4,000 for a significantly long time (Figure 5).

In band B.2, the eastern region, the relative humidity continues to remain high till about $8^{\text {th }}$ February 2021, after which it drops to $60 \%$ and lower. This is followed by a slower rise. One probable cause of the slow rise in band B. 2 could be a very low case incidence of below 300 cases daily for a long time (Figure 6).

iii) Band C

The period of the South-West Monsoon is 20June-2020 to 27-October-2020 and a similar pattern as bands $\mathrm{A}$ and $\mathrm{B}$ is observed, but the decline starts in about 12 weeks from the "official" monsoon arrival date; rains do not start in ALL the states included in this band at the same time. (Further study may be done based on breaking states down further to district levels and rearranging the bands differently). Around late February, the humidity drops below $70 \%$ and lower and an increase in the number of cases is seen in the 34 weeks around mid to late March (Figure 7).

\section{iv) Band D}

This band, with a monsoon duration of 1-July2020 to 12 -Oct-2020, is observed to show the same pattern as Band E. Monsoon-induced humidity appears to cause a decline in cases after about 8-10 weeks from the start of monsoon. Post-monsoon, the humidity drops below $60 \%$ all the way down to $30 \%$ in September and December; this is observed in the specific districts in this band in the Micro-Level study results in the next sub-section. This drop in humidity showed a corresponding increase in daily cases again in about 3-4 weeks. This North-Western region experiences a climatic phenomenon named the "Western Disturbance". This causes rain and increased humidity during the winter season (approximately between October to December) (15). This increased humidity seems to have caused the subsequent decline in cases. After the Western Disturbance rains are over, the humidity is observed to drop below $70 \%$ and lower around early February, causing a case increase in the 3-4 weeks around late-February/early March (Figure 8).

\section{v) Band E}

The monsoon arrives here last in the country and departs first, resulting in the shortest duration. The period of the South- West Monsoon is from 8-July2020 to 25-Sept-2020. Covid-19 cases begin to decline within $8-9$ weeks of the start of the monsoon rains, and thus, the Monsoon Induced Humidity (MIH). Post-monsoon, the humidity drops below $60 \%$ all the way down to $30 \%$ from late-September to mid- November; this is observed in the specific districts in this band in the Micro-Level study results in the next sub-section. This drop in humidity showed a corresponding increase in daily cases again in about 3-4 weeks. This North-Western region also experiences Western Disturbance, as explained in band D. This increased humidity seems to have caused the subsequent decline in cases. After the rains of the Western Disturbance have passed, the humidity is observed to drop below $70 \%$ and lower around mid to late January, causing an increase in cases to occur in the 34 weeks around mid to late February (Figure 9).

\section{Smaller (Micro-level) Locations}

The district level findings are more accurate and provide a clear correlation between relative humidity and case incidence. The increase in relative humidity and the subsequent decline in cases is marked by green circles and the opposite; i.e., drop in relative humidity and subsequent rise in cases is marked in red. Interventions by the local administration or state government (e.g., restrictions, complete, partial, night, or weekend lockdowns, etc.) are marked by the green column labels, while significant relaxations, "unlock", "opening-up" are marked by the Red Column in certain locations. (One chart from each band is given below as figures 10-18).

\section{i) Districts in band $\mathrm{A}$}

This Band A is subdivided into A.1, eastern states, and A.2, western states, as described in the method section. The representative charts of each of the two are shown in Figures 10 and 11.

\section{ii) Districts in band B}

The band $\mathrm{B}$ is subdivided into two bands: B.1, eastern states, and B.2, western states, as described in the method section. Two representative charts for B.1, which is a geographically larger and climatically diverse region, and one representative chart for B.2 are displayed in Figures 12, 13 and 14.

\section{iii) Districts in band $\mathrm{C}$}

The representative charts for $\mathrm{C}$ are displayed in Figures 15 and 16. 


\section{iv) Districts in band D}

The representative chart for $\mathrm{D}$ is presented in Figure 17.

\section{v) Districts in band $\mathrm{E}$ \\ The representative chart for $\mathrm{E}$ is displayed in Figure 18.}

Based on study and analysis of the above results, a definite correlation is observed between relative humidity $(\mathrm{RH})$ and daily cases. After the $\mathrm{RH}$ increases significantly in a region, the daily cases start declining in 8 to 12 weeks (mean of $9.96 \pm 2.81$ weeks)

(Table 1). After the start of the dry, low RH period from mid-January 2021, the cases rapidly started to increase, causing the start of the Second Wave in India in 3 to 5 weeks (mean of $3.50 \pm 0.89$ weeks) (Table 2).

During the First Wave in 2020, it has been seen that after the peak/maximum $\mathrm{RH}$ in a region is reached, daily cases start declining. After the end of the first high $\mathrm{RH}$ period post monsoon, when the RH drops significantly, the cases show an increasing trend in about 3 to 5 weeks (mean of $4.33 \pm 1.56$ weeks) (Table 3). In the regions where $\mathrm{RH}$ increases due to Western Disturbances in winter and other climatic events like cyclones, the number of cases declines again further in about 2 to 4 weeks (mean of $3.00 \pm$ 0.80 weeks) (Table 4 ).

\section{Discussion}

During the first wave of 2020, it was observed that after the RH increased significantly, $80.77 \%$ of the total districts studied showed declining incidence rates in 8 to 12 weeks. Some of these districts experience a drier period following the monsoon, with RH suddenly dropping, which is followed by an increase in incidence rates in $83.33 \%$ of districts within 3 to 5 weeks. Due to another high RH period, $80 \%$ of districts experienced a decline within 3 to 5 weeks, with $20 \%$ experiencing a decline even sooner. As in the first wave, $88.46 \%$ of districts had rising incidence rates for 3 to 5 weeks during the second wave of 2021.

There have been similar recent studies specific to Covid-19. These show environmental factors do influence the severity of the disease, as well as incidence rates. Apart from RH, other factors, like the ultra-violet (UV) index and temperature, are also thought to have an effect.
Several other studies on influenza enveloped viruses show that the virus's viability is highest at low RH (below 50\%) and decreases as RH increases. Apparently, the mechanism is not clearly understood, and there are hypotheses about increased aerosol weight due to vapor absorption making them fall to the ground quicker, a change in the salinity of the aerosols, etc. Coronaviruses are enveloped viruses like influenza, and hence, the effects are more likely to be similar. The exact relation between an increase in humidity and a decrease in cases, or the viability of the virus, or R0 (R-naught) in epidemiological terms, is not linear. Further studies can be done based on how the R0 changed with respect to the humidity.

As different studies have considered various environmental factors, in this India-specific study, it was decided to not consider the UV Index as the incidence rate declines during the monsoon, when the UV Index is low due to cloud cover and humidity. Similarly, temperature was also not considered, as increased incidence rates have been observed in warmer as well as colder temperatures. Another aspect this study did not address was coastal locations that are highly humid all year around, with relatively smaller change in RH but even these small changes did show up in corresponding incidence rate changes can be addressed in the R0 studies mentioned above.

One of the important strengths of this study is that it is easy to construct with just two parameters and can be conducted in a short time. One limitation of the current study is the role of government interventions (restrictions/lockdowns) in flattening the curve. However, it was not investigated how much of an effect this had on the start and duration of the case decline.

This study hypothesizes that COVID19/SARS-COV2 shows a National Seasonality of reaching peak and starting decline in the middle of the monsoon season, around mid-September depending on start and progression of monsoon and reaching lows in following January/February.

\section{Conclusion}

The is an ongoing study started in October 2020 and the prediction made by this hypothesis about a period of an increase in cases has come true so far, which is now called the second Covid-19 wave in India. And, if this hypothesis is correct, and there are no government interventions, such as lockdowns, curfews, and so on, the subsequent natural second wave/case peak is expected to be seen around the middle of September 2021. The second wave is likely to show a sharp rise, worse than the first wave, due to high prevalence as well as getting a longer dry season 
to spread than the first wave of 2020, which started in May-June 2020 with a much lower prevalence. Government interventions may result in not having a continuous exponential curve and may show periodic slowing or plateauing before the decline starts. Understanding seasonality will help in the provision of health care infrastructure, medicines, and the development of timely public awareness campaigns. This will enable us to conduct mass

\section{References}

1. WorldOmeter. 2021 [cited 2021 Apr 28]. Available from: https://www.worldometers.info/worldpopulation/population-by-country/.

2. Singh, A., Deedwania, P., Vinay, K. M., Khanna, M.P. Is India's Health Care Infrastructure Sufficient for Handling COVID-19 Pandemic? Int Arch Public Health Community Med 2020; 4(2):041.

3. Khanna, A. Impact of Migration of Labour Force. J Health Management 2020; 22(2):181-191.

4. Yu, X., Qi, G., Hu, J. Analysis of second outbreak of COVID-19 after relaxation. Nonlinear Dyn 2020 Oct 10:1-19.

5. Jaakkola, K., Saukkoriipi, A., Jokelainen, J., Juvonen, R., Kauppila, J., Vainio, O. et al. Decline in temperature and humidity increases the occurrence of influenza in cold climate. Environ Health. 2014;13: 22.

6. Shaman, J., Pitzer, V., Viboud, C., BT G, Lipsitch, M. Absolute Humidity and the Seasonal Onset of Influenza in the Continental United States. PLOS Biol 2010;8(2):e1000316.

7. Lowen, A.C., Steel, J. Roles of Humidity and Temperature in Shaping Influenza Seasonality. J Virol 2014; 88(14):7692-7695.

8. Yang, W., Elankumaran, S., Marr, L. Relationship between humidity and influenza A viability in droplets and implications for influenza's seasonality. PLOS One 2012;7(10): e46789.

9. Domagoj, K. Effects of Environmental Factors on Severity and Mortality of COVID-19. Frontiers in Medicine 2021;7:607786.

10. Tobías, A., Molina, T., Rodrigo, M., Saez, M. Meteorological factors and incidence of COVID-19 during the first wave of the pandemic in Catalonia (Spain): A multi-county study. One Health. 2021;12:100239.

11. Tang, J.W. The effect of environmental parameters on the survival of airborne infectious agents. J Roy Soc Interface 2009; 6(6) (Suppl 6):S737-S746.

12. Yang, W., Marr, L.C. Mechanisms by Which Ambient Humidity May Affect Viruses in Aerosols. Appl Environ Microbiol 2012;78(19):6781-6788. vaccination drives in a time-bound manner along with studies of vaccine effectiveness durations and prepare for booster vaccinations, if needed. The study can further be extended to the neighboring countries of India and other parts of the world where the seasonal patterns of humidity are present. The study is relatively simple to conduct and can be conducted in future outbreaks to take timely preventive measures.

13. Price, R.H.M., Graham, C., Ramalingam, S. Association between viral seasonality and meteorological factors. Scientific Reports 2019;9:929. 14. Ministry of Earth Sciences, Government of India. India Meteorological Department. New Delhi; 2020. Available from: https://mausam.imd.gov.in/imd_latest/contents/seaso $\underline{\text { n report.php. }}$.

15. Dimri, A.P., Niyogi, D., Barros, A.P., Ridley, J., Mohanty, U.C., Yasunari, T., Sikka, R. Western Disturbances: A review. Rev Geophys 2015;53(2):225-246.

16. Ministry of Earth Sciences, Government of India. India Meteorological Department. New Delhi; 2020. Available

from:

https://mausam.imd.gov.in/imd_latest/contents/mons

oon.php.

17. Rajeevan, M., Unnikrishnan, C.K., Bhate, J., Niranjan Kumar, K., Sreekala, P.P. Northeast monsoon over India: variability and prediction. Meteorol Appl 2012;19(2):226-236.

18. Ministry of Earth Sciences, Government of India. India Meteorological Department. New Delhi; 2020. Available from:

https://mausam.imd.gov.in/backend/assets/press_rele ase _pdf/press-release19.pdf.

19. Ministry of Earth Sciences, Government of India. India Meteorological Department.. New Delhi; 2020. Available

from:

https://mausam.imd.gov.in/backend/assets/press_rele ase_pdf/Press_Release6 dated 5th_December 2020.pdf. 


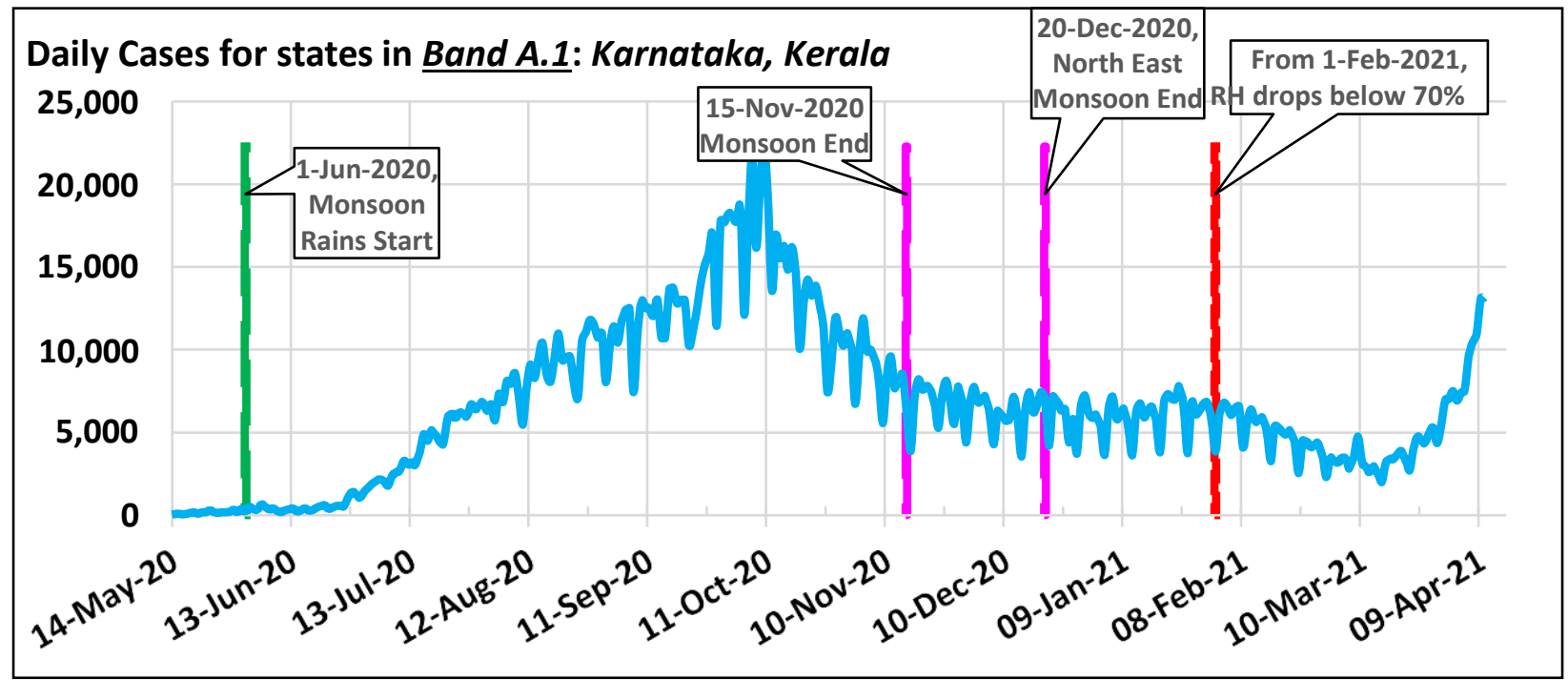

Figure 3. Band A.1 (Regional/Mid)-level

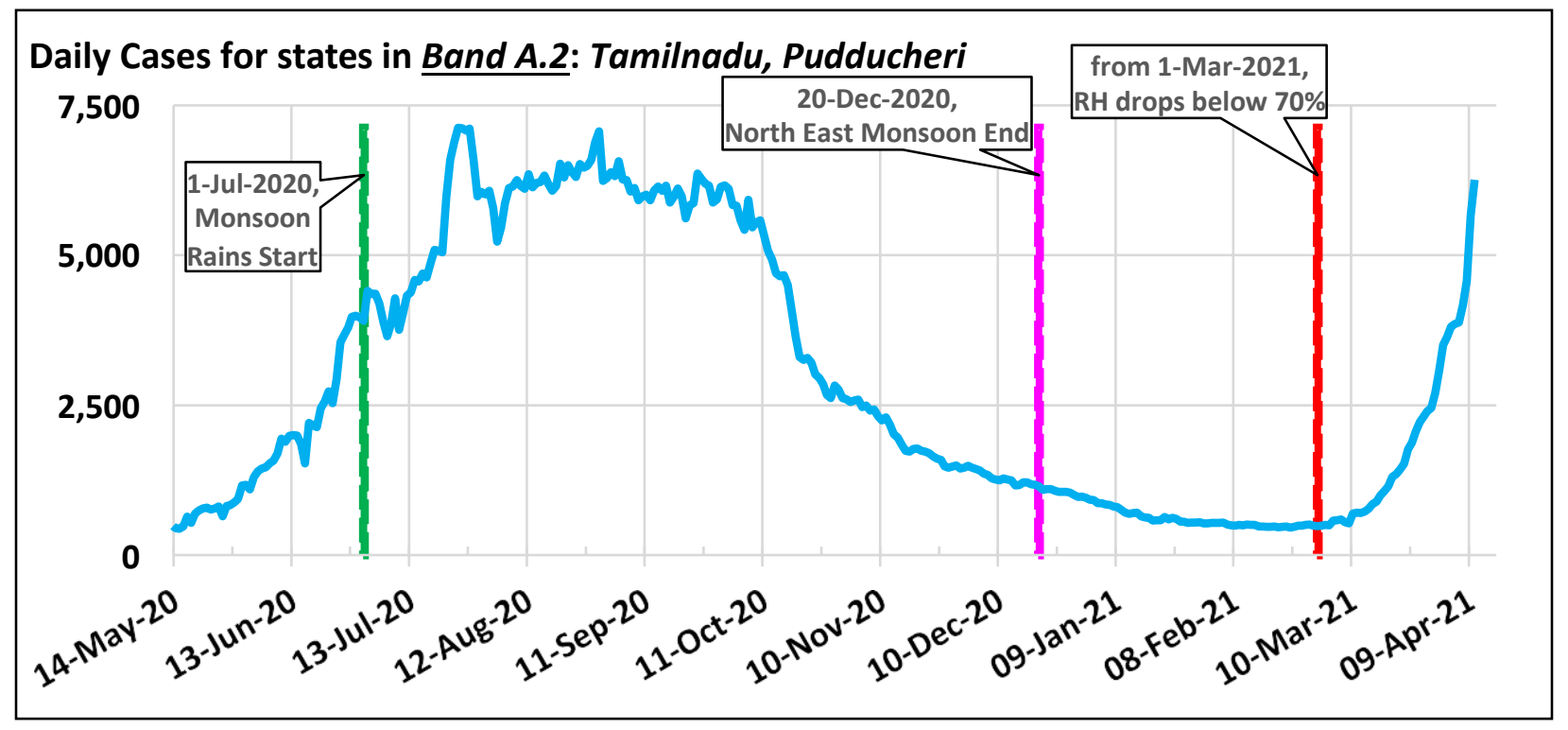

Figure 4. Band A.2 (Regional/Mid)-level 


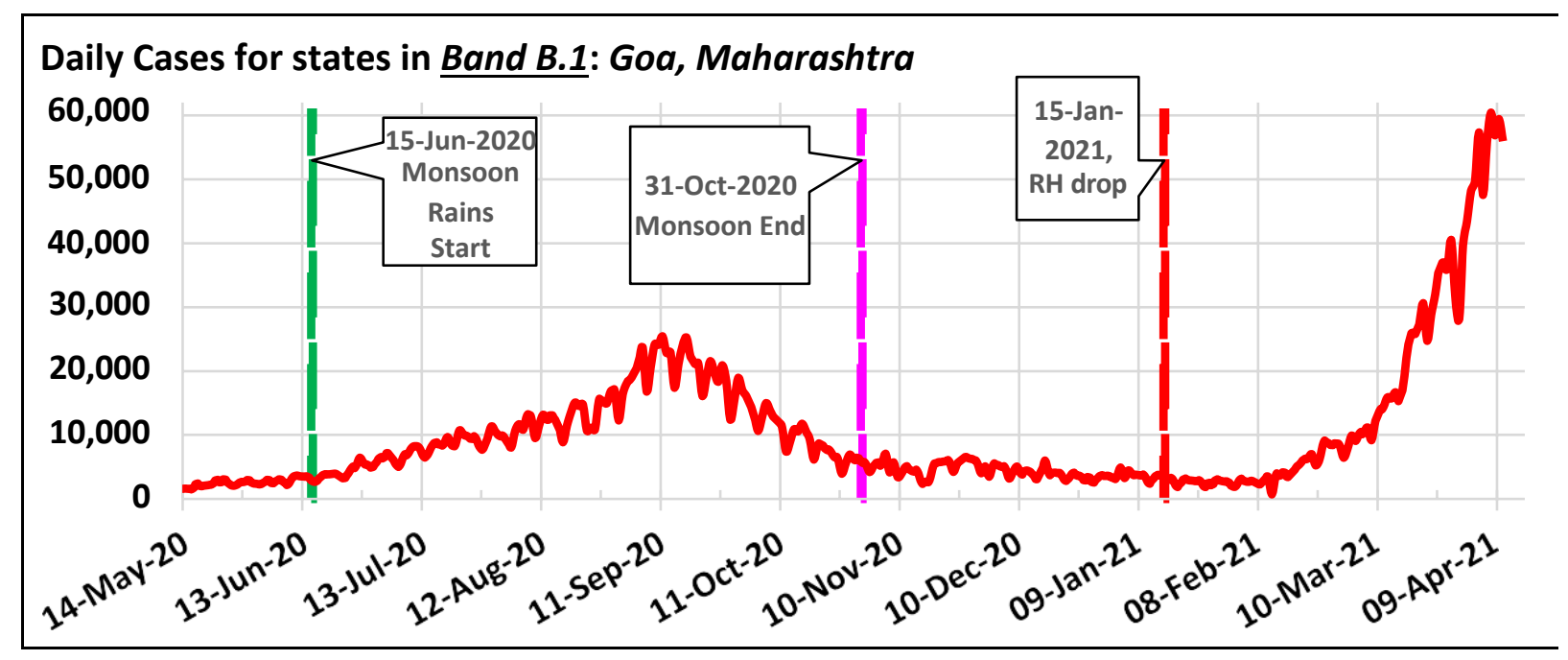

Figure 5. Band B.1 (Regional/Mid)-level

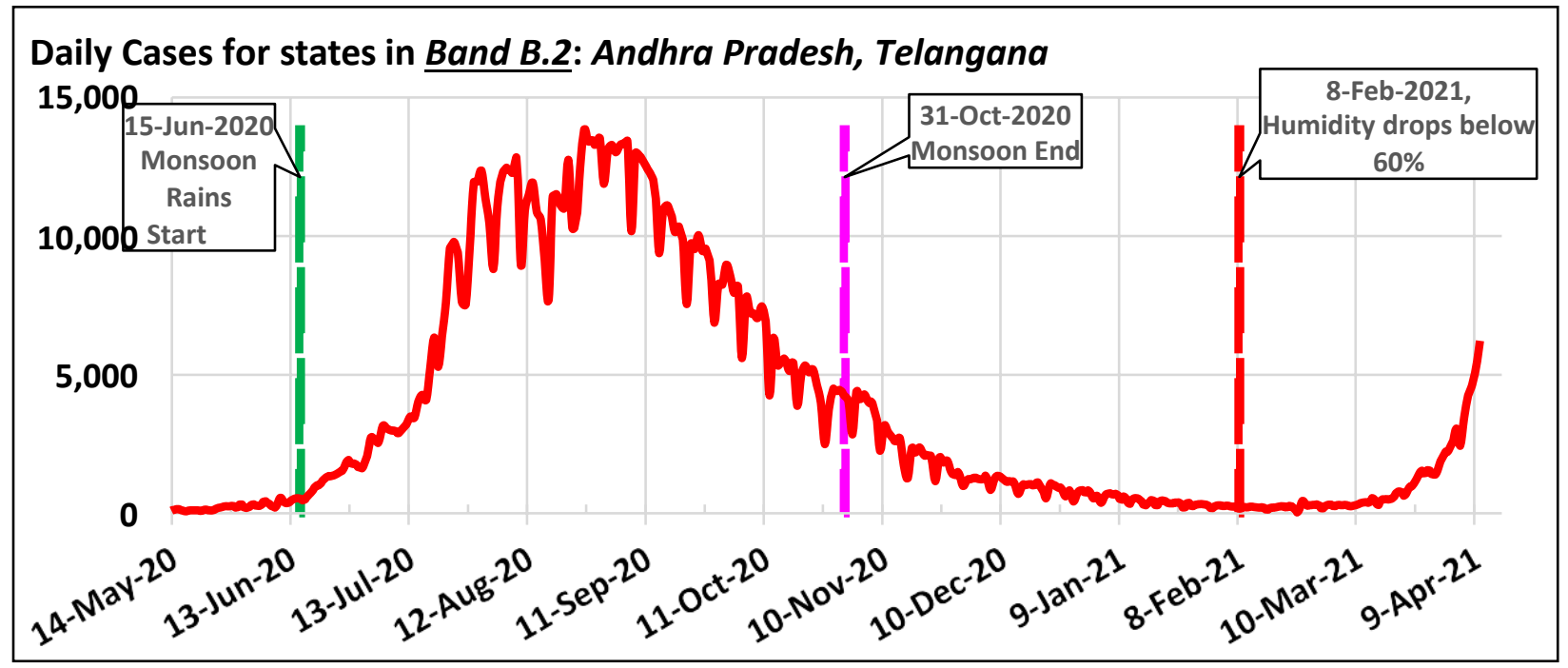

Figure 6. Band B.2 (Regional/Mid)-level 


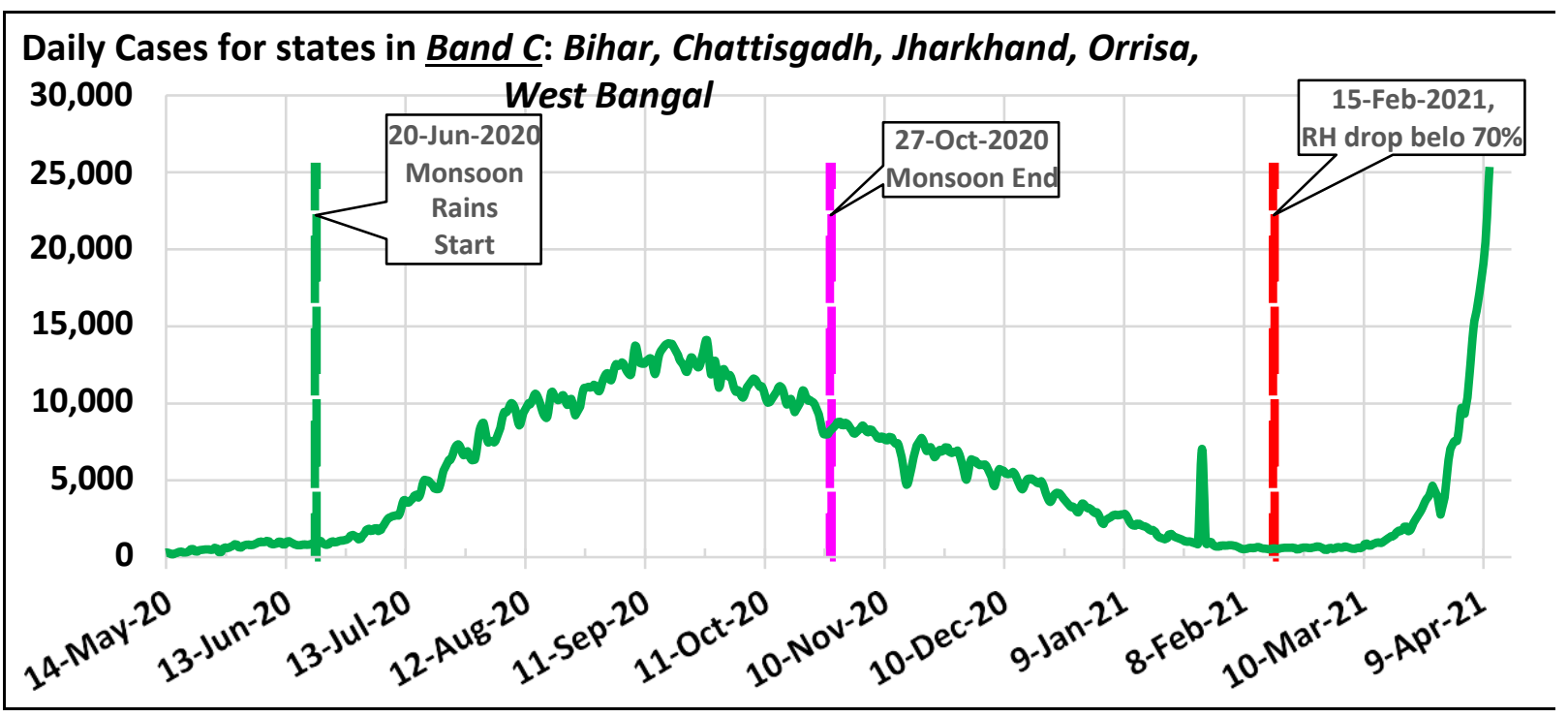

Figure 7. Band C (Regional/Mid)-level

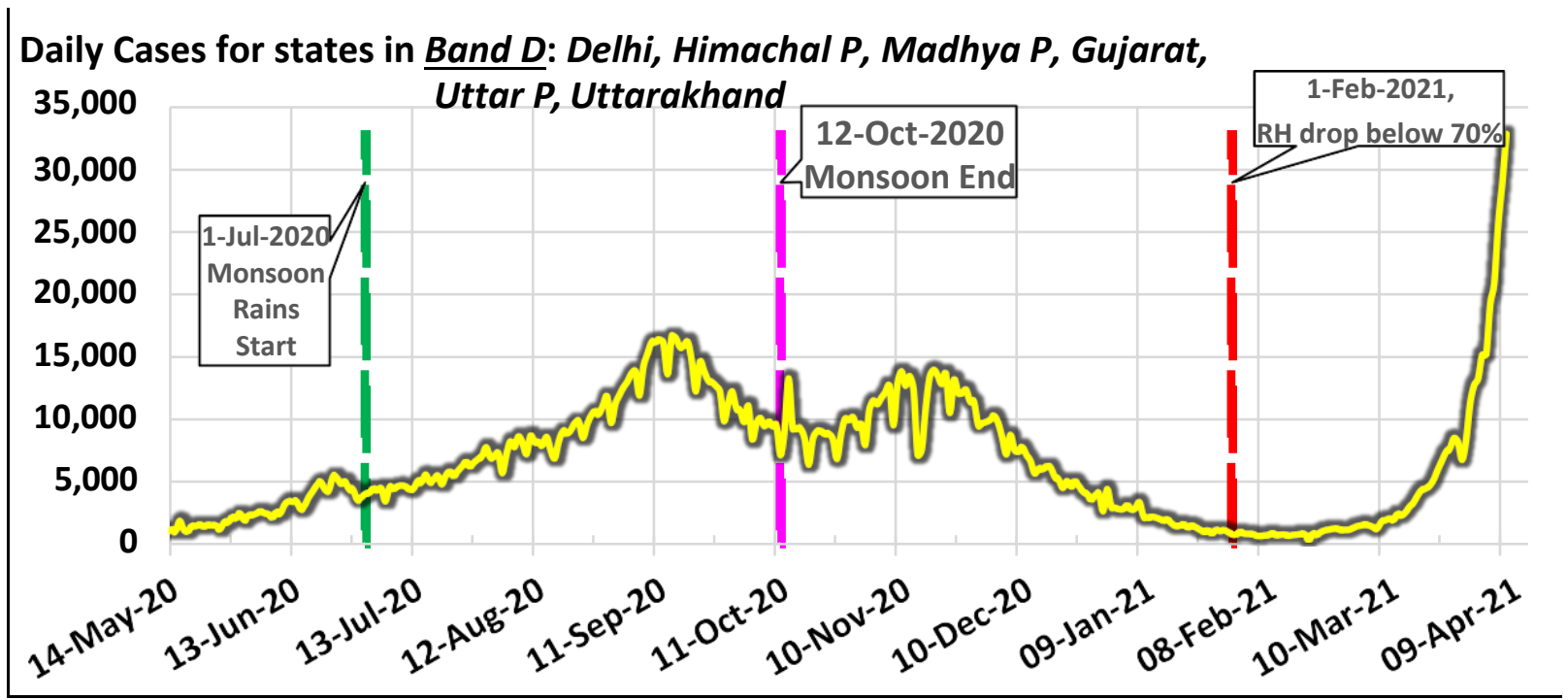

Figure 8. Band D (Regional/Mid)-level 


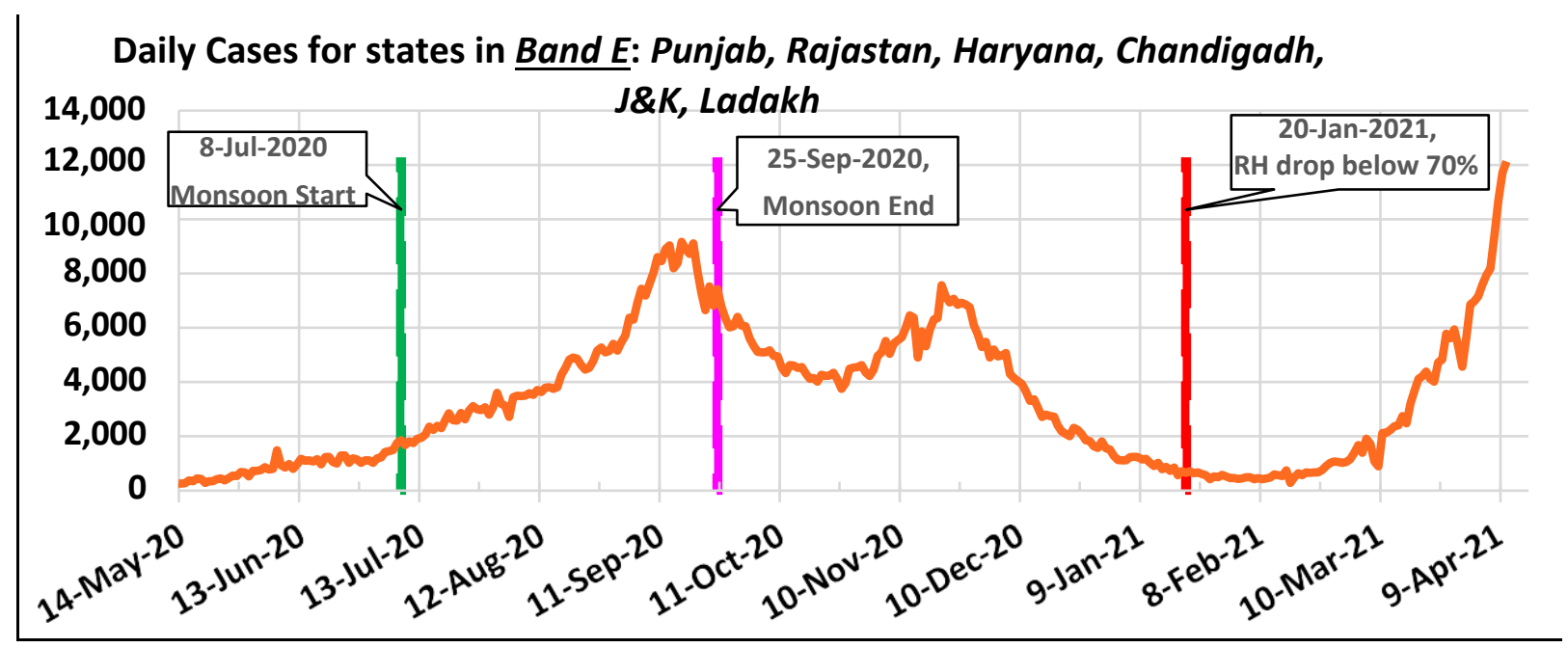

Figure 9. Band E (Regional/Mid)-level

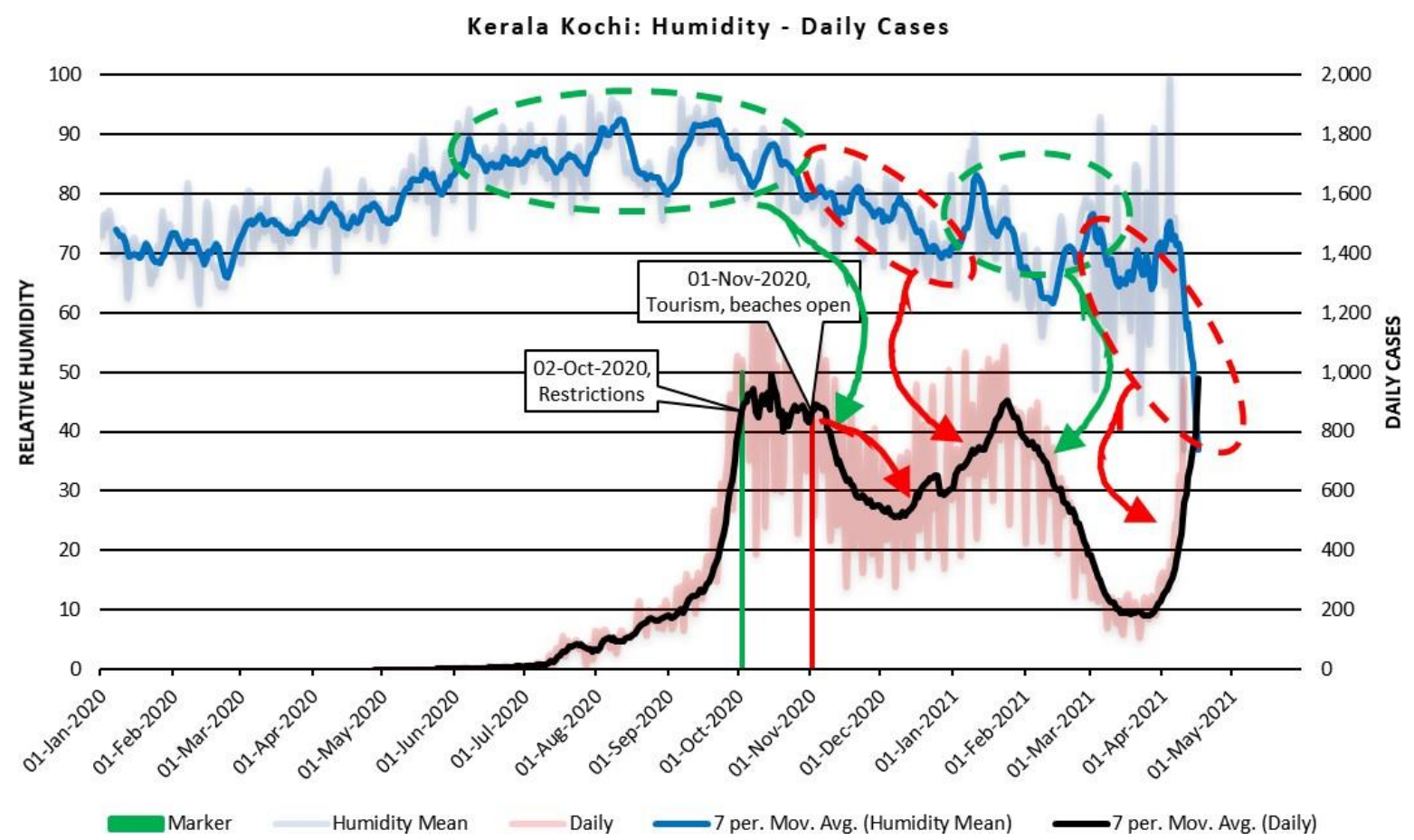

Figure 10. Band A.1 - District 1 of 2 (Micro-level) 


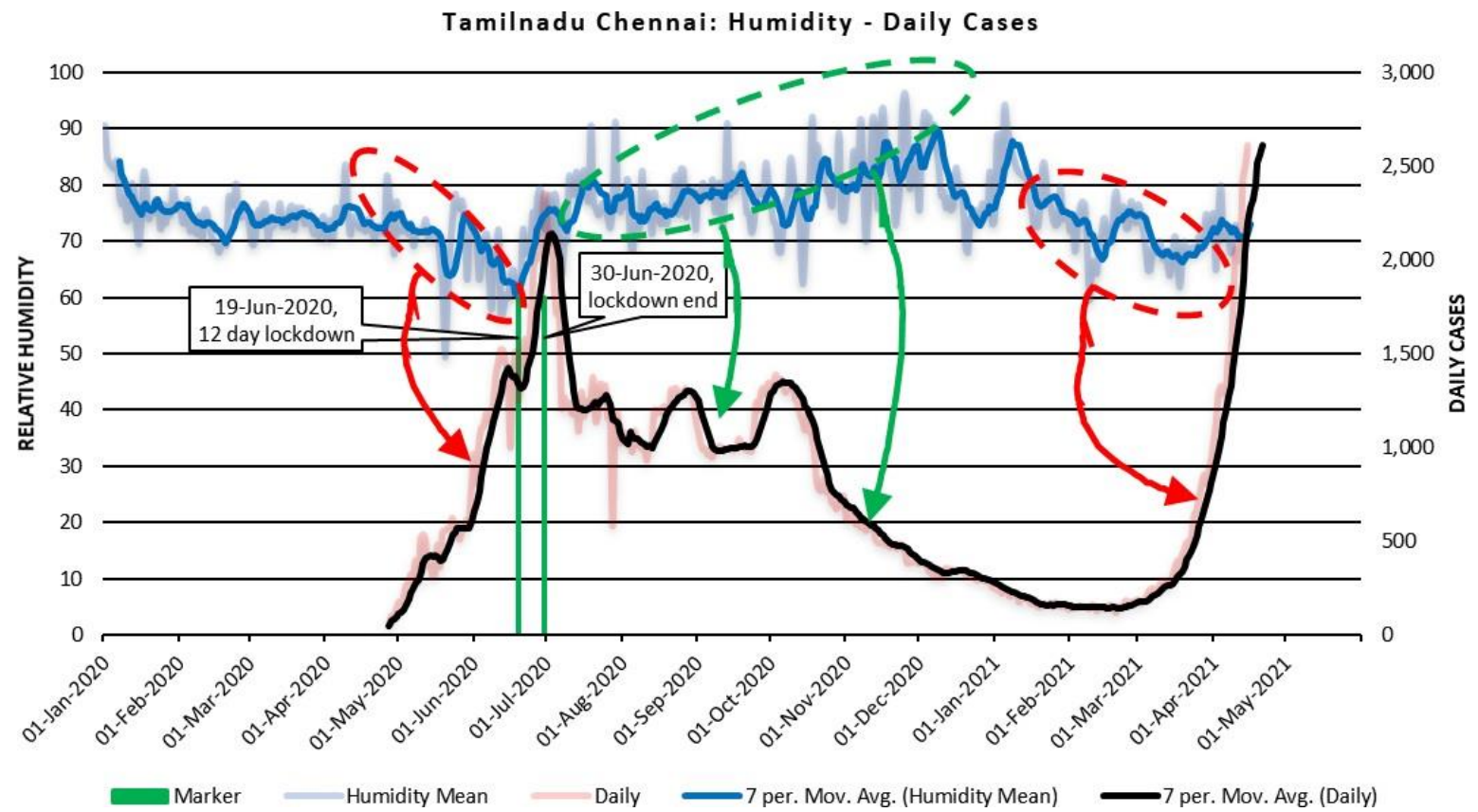

Figure 11. Band A.2 - District 1 of 2 (Micro-level)

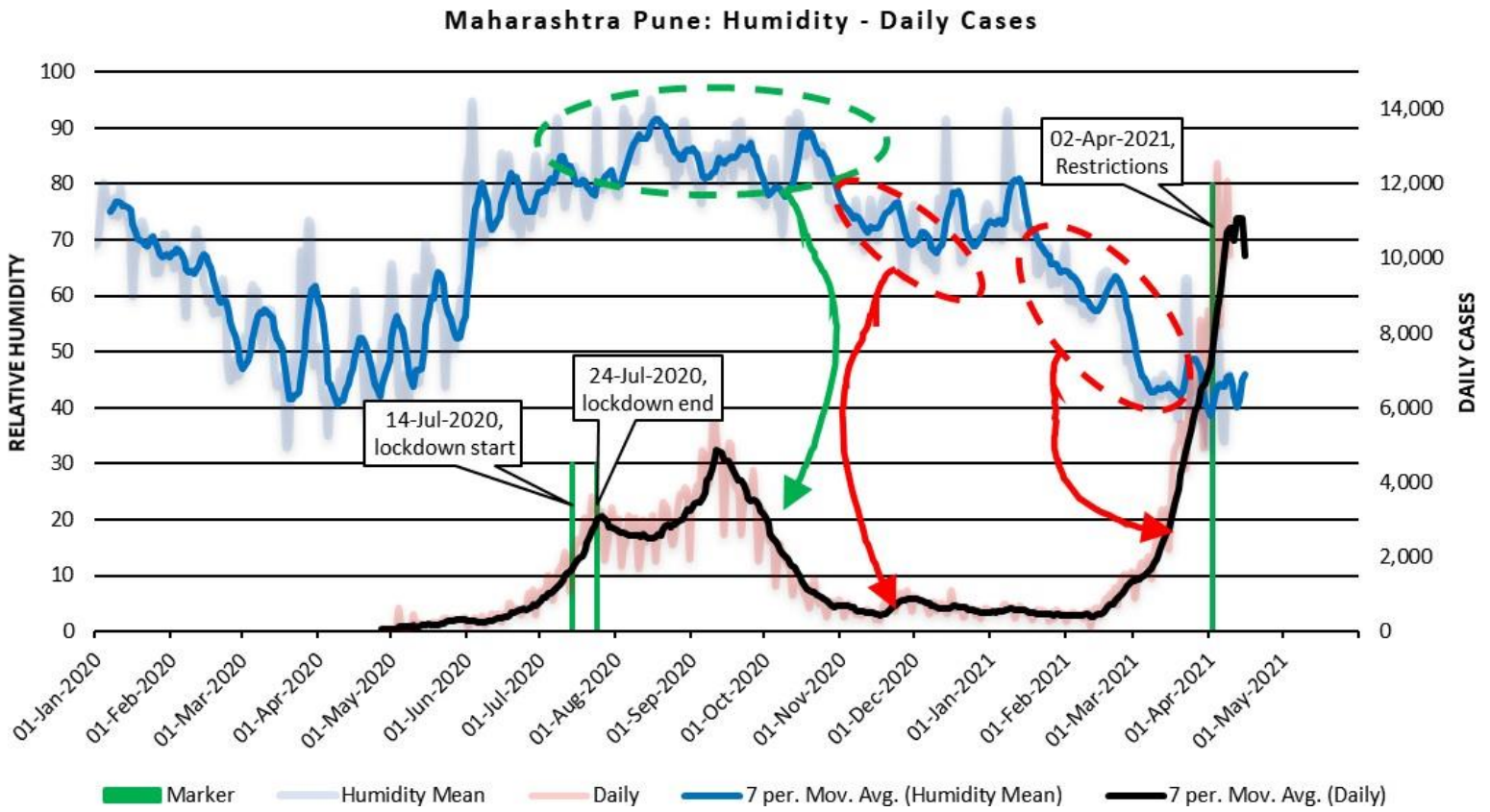

Figure 12. Band B.1 - District 1 of 8 (Micro-level) 
Mumbai District: Humidity - Daily Cases

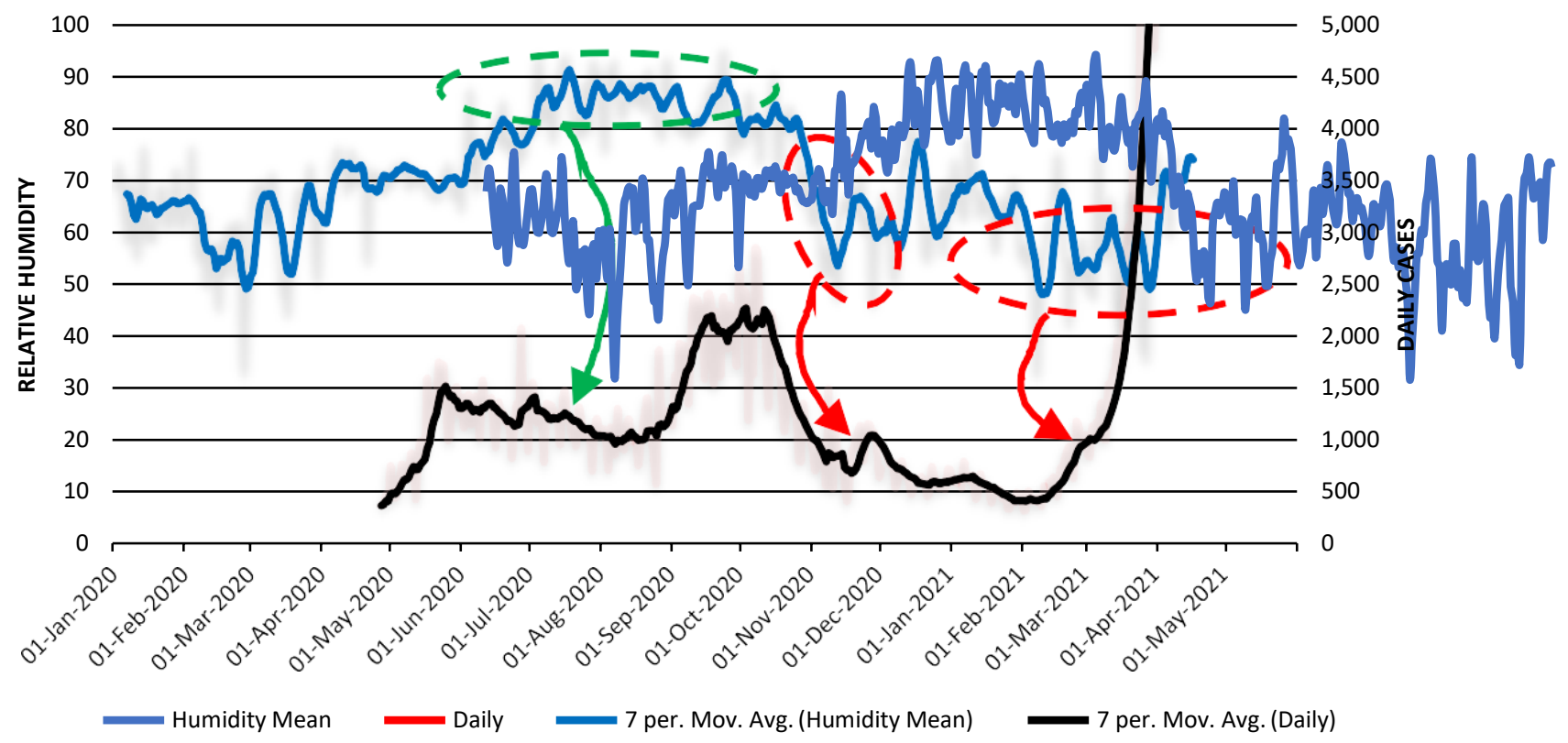

Figure 13. Band B.1 - District 2 of 8 (Micro-level)

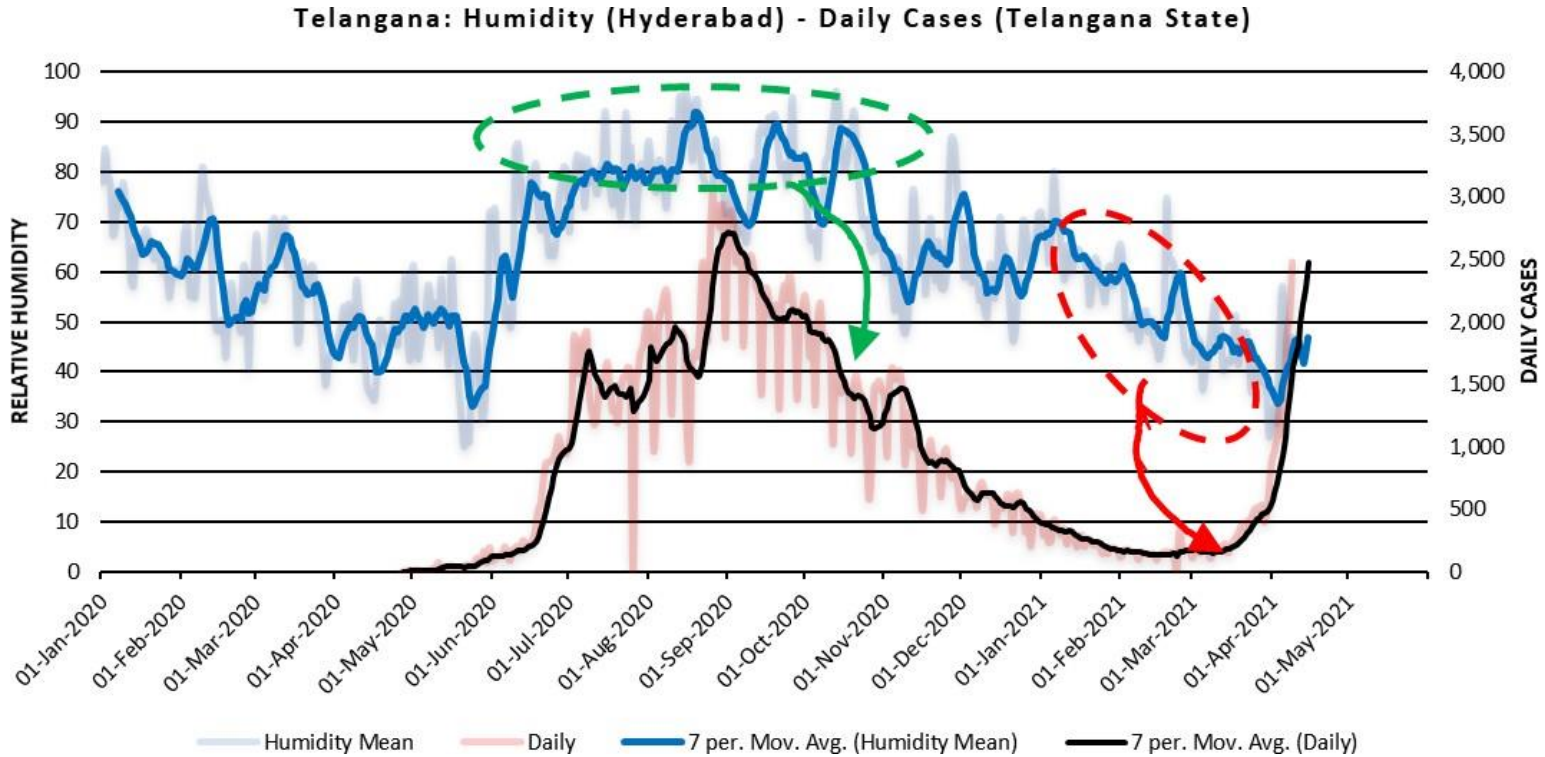

Figure 14. Band B.2 - District 1 of 2 (Micro-level) 
Kolkata District: Humidity - Daily Cases

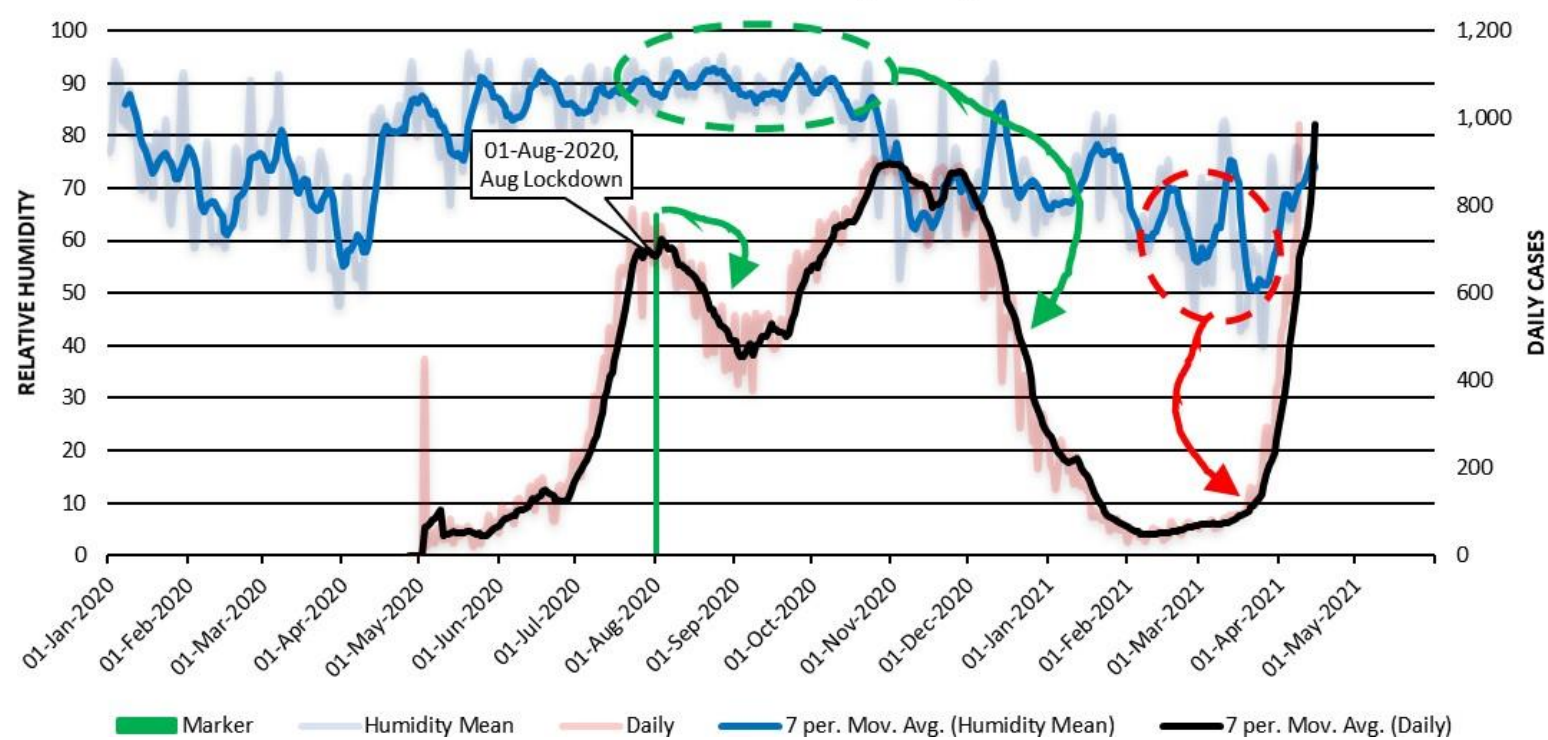

Figure 15. Band C - District 1 of 5 (Micro-level)

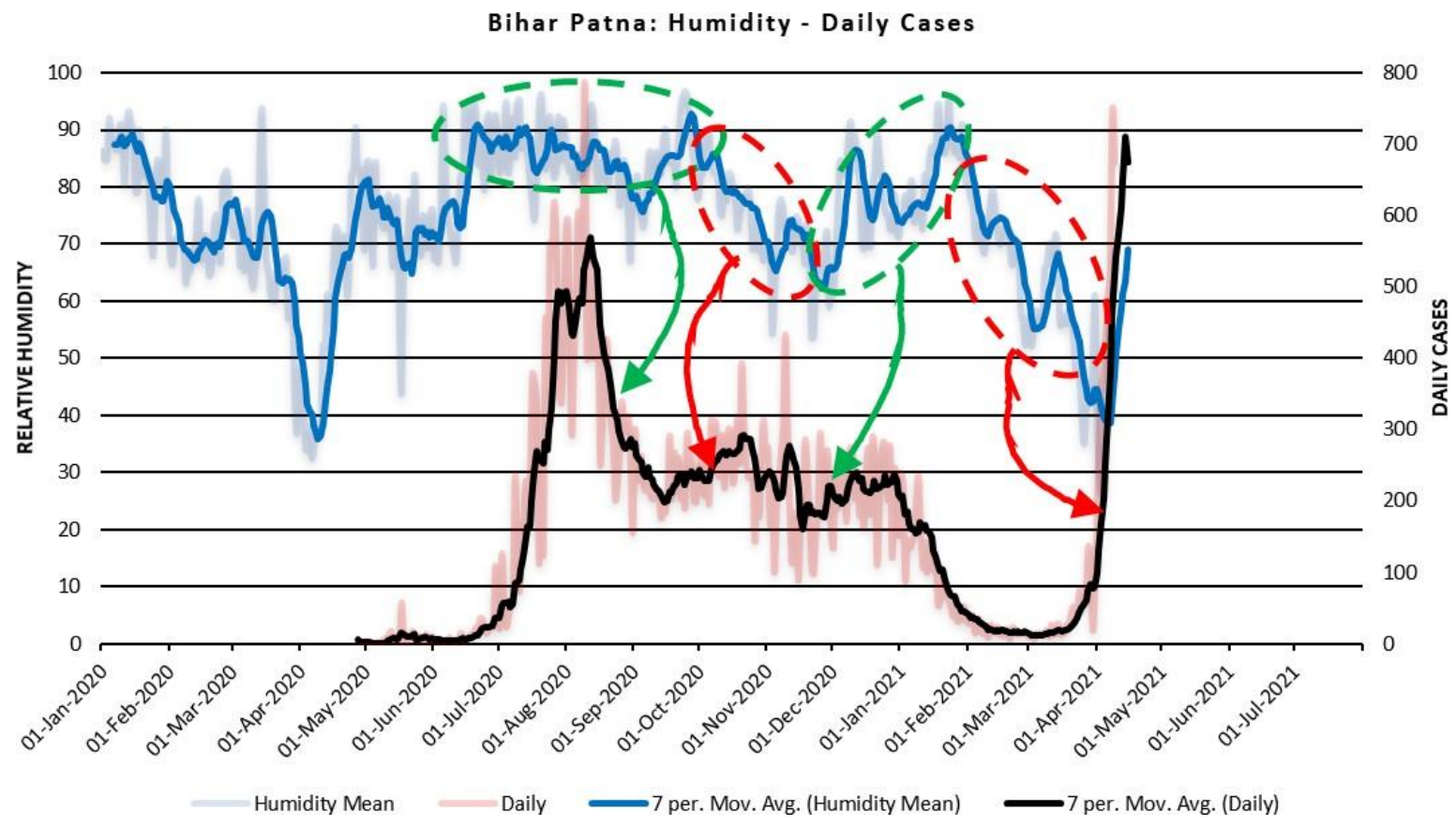

Figure 16. Band C - District 2 of 5 (Micro-level) 


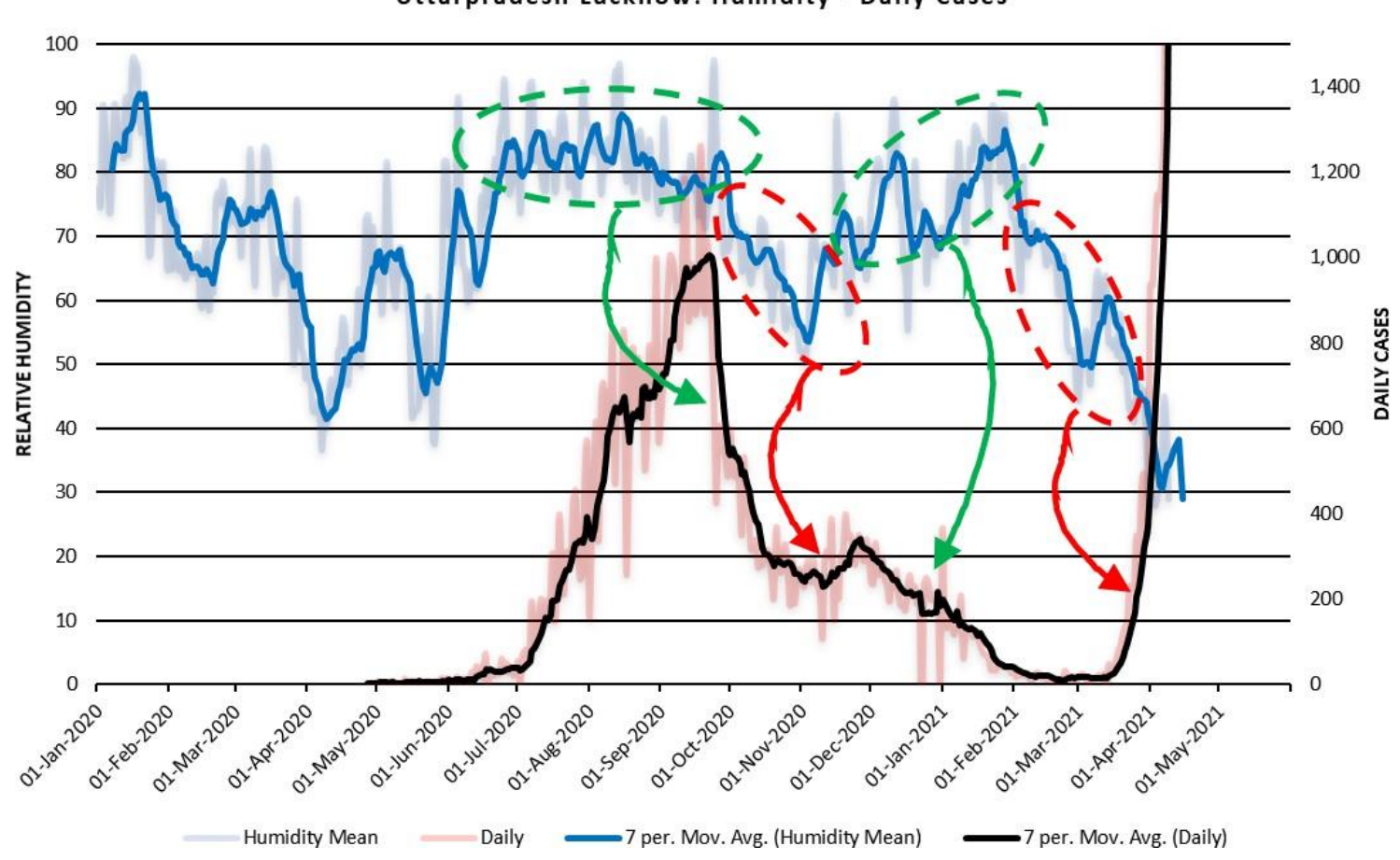

Figure 17. Band D - District 1 of 5 (Micro-level)

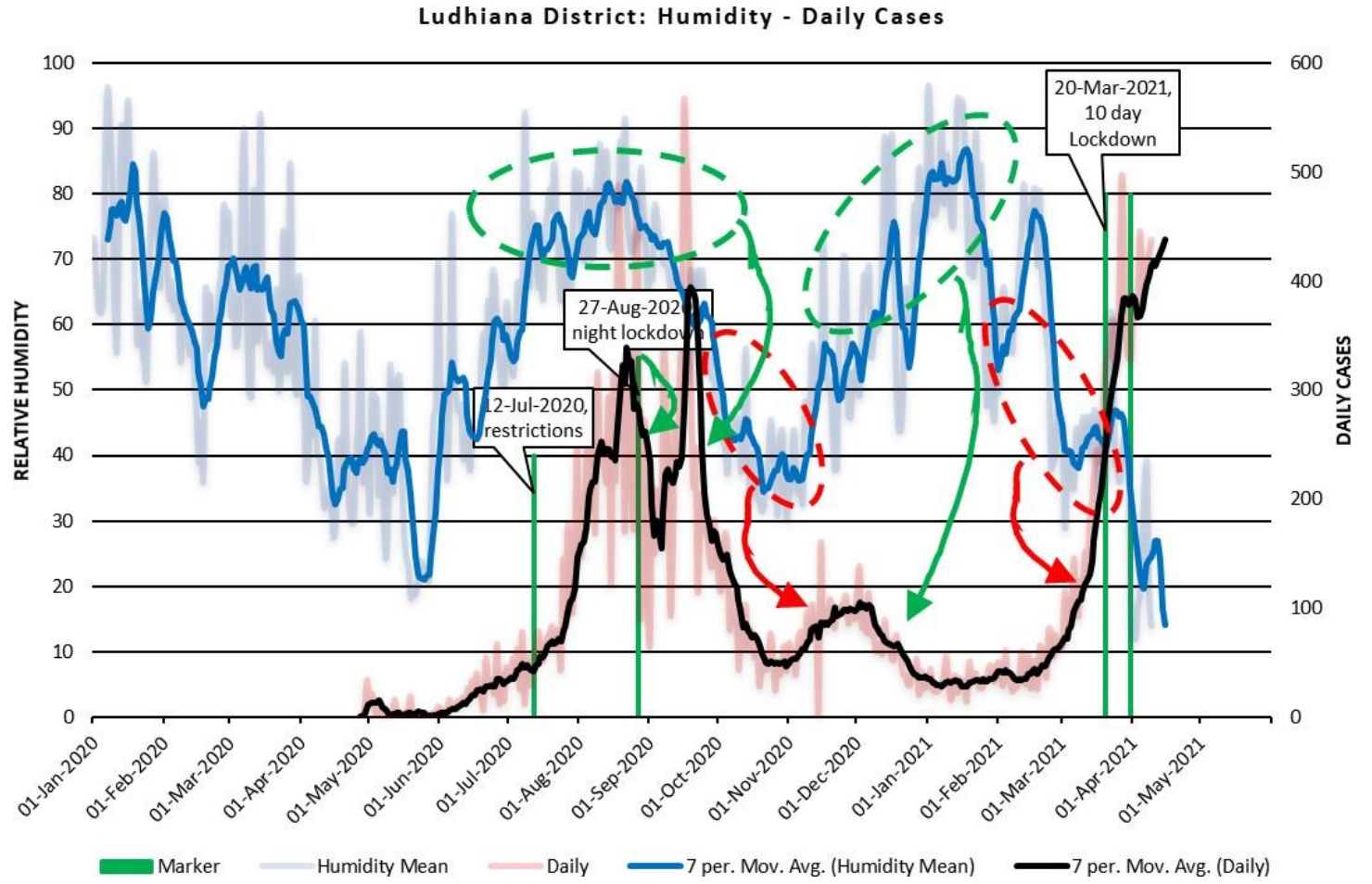

Figure 18. Band E - District 1 of 2 (Micro-level) 
Humidity and Covid-19 correlation in India

Table 1. Time to begin a declining trend in daily cases after Relative Humidity $(\mathrm{RH})$ rise due to monsoon rains in the first wave $-1^{\text {st }}$ Peak of 2020

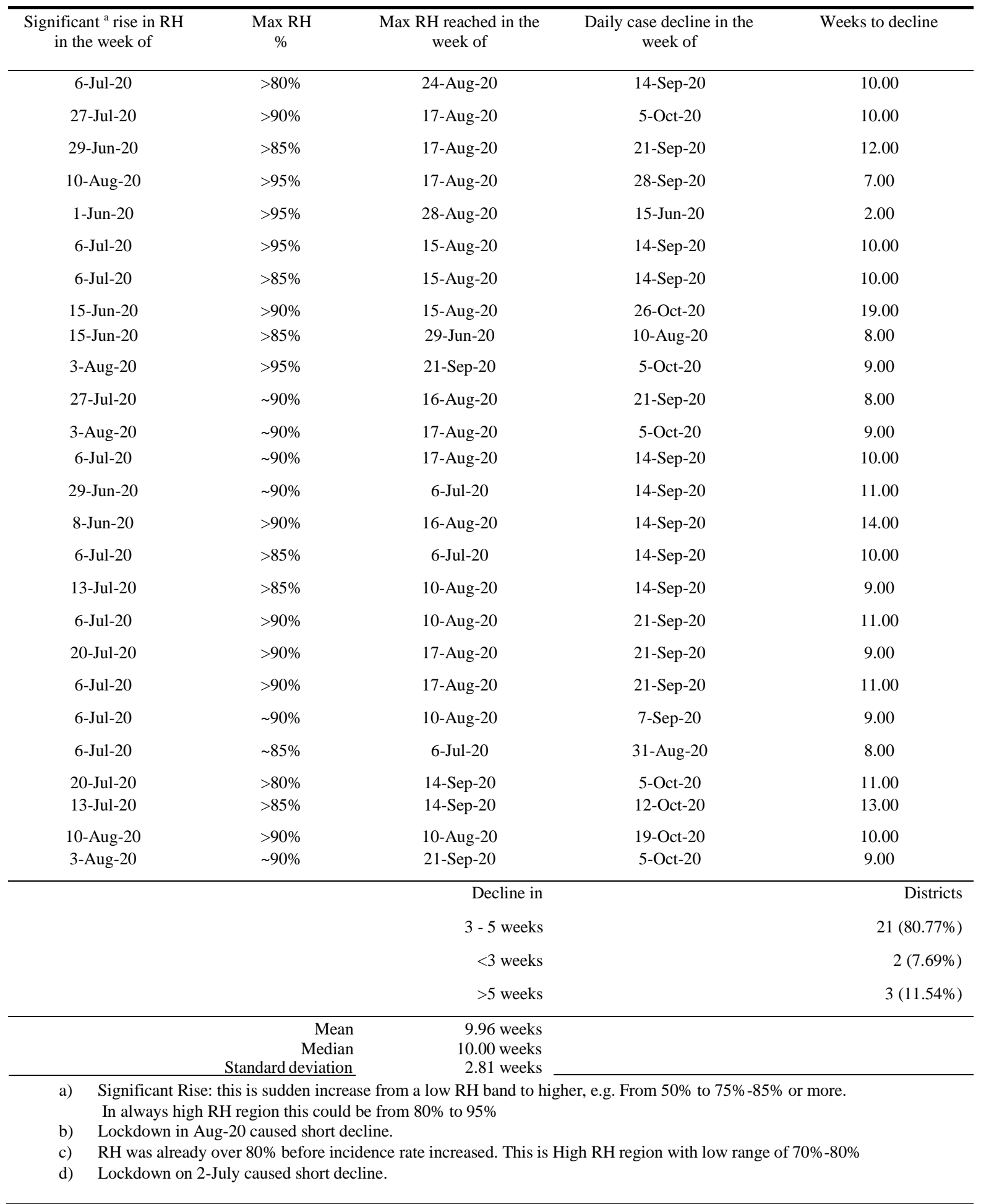


Mane, V. et al.

Table 2: Time to begin an increasing trend in daily cases after Relative Humidity $(\mathrm{RH})$ drops after dry period start. The second wave, 2021

\begin{tabular}{|c|c|c|c|c|c|}
\hline$\#$ & District, State & Band & $\begin{array}{l}\text { Significant }{ }^{\mathrm{a}} \text { Drop in } \\
\text { RH in the week of }\end{array}$ & $\begin{array}{l}\text { Daily Case Increase } \\
\text { Stated in the week of }\end{array}$ & Weeks to Rise \\
\hline 1 & Ludhiana, Punjab & $\mathrm{E}$ & 25-Jan-21 & $22-F e b-21$ & 4.00 \\
\hline 2 & Jaipur, Rajasthan & $\mathrm{E}$ & 1-Mar-21 & 22-Mar-21 & 3.00 \\
\hline 3 & Lucknow, Uttar Pradesh & $\mathrm{D}$ & 22-Feb-21 & 15-Mar-21 & 3.00 \\
\hline 4 & Bhopal, Madhya Pradesh & $\mathrm{D}$ & 25-Jan-21 & 22-Feb-21 & 4.00 \\
\hline 5 & Ahmedabad, Gujarat & $\mathrm{D}$ & 25-Jan-21 & $22-F e b-21$ & 4.00 \\
\hline 6 & Dehradun, Uttarakhand & $\mathrm{D}$ & 1-Mar-21 & 22-Mar-21 & 3.00 \\
\hline 7 & Delhi & $\mathrm{D}$ & $22-F e b-21$ & 15-Mar-21 & 3.00 \\
\hline 8 & Kolkata, West Bengal & $\mathrm{C}$ & $22-F e b-21$ & 22-Mar-21 & 4.00 \\
\hline 9 & Patna, Bihar & $\mathrm{C}$ & 22-Feb-21 & 22-Mar-21 & 4.00 \\
\hline 10 & Bhubaneswar, Odisha & $\mathrm{C}$ & $22-F e b-21$ & 29-Mar-21 & 5.00 \\
\hline 11 & Raipur, Chhattisgarh & $\mathrm{C}$ & $22-F e b-21$ & 15-Mar-21 & 3.00 \\
\hline 12 & Ranchi, Jharkhand & $\mathrm{C}$ & $22-F e b-21$ & 15-Mar-21 & 3.00 \\
\hline 13 & Pune, Maharashtra & B. 1 & 18-Jan-21 & $15-F e b-21$ & 4.00 \\
\hline 14 & Mumbai, Maharashtra & B. 1 & 1-Feb-21 & $15-\mathrm{Feb}-21$ & 2.00 \\
\hline 15 & Aurangabad, Maharashtra & B. 1 & 25-Jan-21 & $15-F e b-21$ & 3.00 \\
\hline 16 & Thane, Maharashtra & B. 1 & 1-Feb-21 & $15-\mathrm{Feb}-21$ & 2.00 \\
\hline 17 & Jalgaon, Maharashtra & B. 1 & 25-Jan-21 & $15-\mathrm{Feb}-21$ & 3.00 \\
\hline 18 & Nagpur, Maharashtra & B. 1 & 25-Jan-21 & $15-F e b-21$ & 3.00 \\
\hline 19 & Nashik, Maharashtra & B.1 & 18-Jan-21 & 8-Feb-21 & 3.00 \\
\hline 20 & Amaravati, Maharashtra & B.1 & 11-Jan-21 & 1-Feb-21 & 3.00 \\
\hline 21 & Hyderabad, Telangana & B. 2 & $15-F e b-21$ & 15-Mar-21 & 4.00 \\
\hline 22 & Visakhapatnam, Andhra Pradesh & B. 2 & $22-F e b-21$ & 29-Mar-21 & 5.00 \\
\hline 23 & Chennai, Tamilnadu & A. 2 & 1-Feb-21 & 1-Mar-21 & 4.00 \\
\hline 24 & Bangalore, Karnataka & A. 2 & 1-Feb-21 & 8-Mar-21 & 5.00 \\
\hline 25 & Kochi, Kerala & A. 1 & 8-Mar-21 & 22-Mar-21 & 2.00 \\
\hline \multirow[t]{8}{*}{26} & Thiruvananthapuram, Kerala & A. 1 & 8 -Feb-21 & 15-Mar-21 & 5.00 \\
\hline & & & & Increase in & Districts \\
\hline & & & & 3 - 5 weeks & $23(88.46 \%)$ \\
\hline & & & & $<3$ weeks & $3(11.54 \%)$ \\
\hline & & & & $>5$ weeks & $0(0 \%)$ \\
\hline & & & Mean & 3.50 weeks & \\
\hline & & & Median & 3.00 weeks & \\
\hline & & & Standard Deviation & 0.89 weeks & \\
\hline
\end{tabular}

a) Significant Drop: sudden drop from high RH band to lower 
Table 3: Time to begin an increase trend in daily cases after Relative Humidity (RH) drops after Monsoon rains in the first wave of 2020 and before western disturbances RH rise

\begin{tabular}{|c|c|c|c|c|c|}
\hline$\#$ & District, State & Band & $\begin{array}{l}\text { Significant }{ }^{\mathrm{a}} \text { Drop } \\
\text { in RH in the week } \\
\text { of }\end{array}$ & $\begin{array}{l}\text { Daily Case Increase } \\
\text { Stated in the week of }\end{array}$ & Weeks to Rise \\
\hline 1 & Ludhiana, Punjab & $\mathrm{E}$ & 14-Sep-20 & 2-Nov-20 & 7.00 \\
\hline 2 & Jaipur, Rajasthan & $\mathrm{E}$ & 7-Sep-20 & 9-Nov-20 & 9.00 \\
\hline 3 & Lucknow, Uttar Pradesh & $\mathrm{D}$ & 12-Oct-20 & 9-Nov-20 & 4.00 \\
\hline 4 & Bhopal, Madhya Pradesh & $\mathrm{D}$ & 28-Sep-20 & 2-Nov-20 & 5.00 \\
\hline 5 & Ahmedabad, Gujarat & $\mathrm{D}$ & 5 -Oct- 20 & 9-Nov-20 & 5.00 \\
\hline 6 & Dehradun, Uttarakhand & $\mathrm{D}$ & 5 -Oct-20 & 2-Nov-20 & 4.00 \\
\hline 7 & Delhi & $\mathrm{D}$ & 14-Sep-20 & $12-$-Oct-20 & 4.00 \\
\hline 8 & Kolkata, West Bengal ${ }^{\mathbf{b}}$ & $\mathrm{C}$ & - & - & - \\
\hline 9 & Patna, Bihar & $\mathrm{C}$ & 26-Oct-20 & 16-Nov-20 & 3.00 \\
\hline 10 & Bhubaneswar, Odisha ${ }^{\mathbf{b}}$ & $\mathrm{C}$ & - & - & - \\
\hline 11 & Raipur, Chhattisgarh ${ }^{\mathbf{b}}$ & $\mathrm{C}$ & - & - & - \\
\hline 12 & Ranchi, Jharkhand ${ }^{\mathbf{b}}$ & $\mathrm{C}$ & - & - & - \\
\hline 13 & Pune, Maharashtra & B. 1 & 26-Oct-20 & 16-Nov-20 & 3.00 \\
\hline 14 & Mumbai, Maharashtra & B. 1 & 26-Oct-20 & 16-Nov-20 & 3.00 \\
\hline 15 & Aurangabad, Maharashtra & B. 1 & $26-$ Oct-20 & 23-Nov-20 & 4.00 \\
\hline 16 & Thane, Maharashtra & B. 1 & $26-$ Oct-20 & 16-Nov-20 & 3.00 \\
\hline 17 & Jalgaon, Maharashtra ${ }^{\mathbf{c}}$ & B. 1 & 26-Oct-20 & 16-Nov-20 & 3.00 \\
\hline 18 & Nagpur, Maharashtra ${ }^{\mathbf{b}}$ & B. 1 & - & - & - \\
\hline 19 & Nashik, Maharashtra & B. 1 & 26-Oct-20 & 23-Nov-20 & 4.00 \\
\hline 20 & Amaravati, Maharashtra $^{c}$ & B. 1 & 19-Oct-20 & 16-Nov-20 & 4.00 \\
\hline 21 & Hyderabad, Telangana ${ }^{\mathbf{c}}$ & B. 2 & 5-Oct-20 & 26-Oct-20 & 3.00 \\
\hline 22 & Visakhapatnam, Andhra Pradesh ${ }^{\mathbf{b}}$ & B. 2 & - & - & - \\
\hline 23 & Chennai, Tamilnadu ${ }^{\mathbf{b}}$ & A. 2 & - & - & - \\
\hline 24 & Bangalore, Karnataka b & A. 2 & - & - & - \\
\hline 25 & Kochi, Kerala & A. 1 & 9-Nov-20 & 7-Dec-20 & 4.00 \\
\hline \multirow[t]{8}{*}{26} & Thiruvananthapuram, Kerala & A. 1 & 30-Nov-20 & 11-Jan-21 & 6.00 \\
\hline & & & & Increase in & Districts \\
\hline & & & & $3-5$ weeks & $15(83.33 \%)$ \\
\hline & & & & $<3$ weeks & $0(0.00 \%)$ \\
\hline & & & & $>5$ weeks & $3(16.67 \%)$ \\
\hline & & & Mean & 4.33 weeks & \\
\hline & & & Median & 4.00 weeks & \\
\hline & & & Standard Deviation & 1.56 weeks & \\
\hline & $\begin{array}{l}\text { Significant Drop: sudden drop fr } \\
\text { No second rise observed during } \\
\text { A short uptrend observed follow }\end{array}$ & $\begin{array}{l}\text { band to } \\
\text { cline. }\end{array}$ & wer. & & \\
\hline
\end{tabular}


Table 4: Time to begin a declining trend in daily cases after Relative Humidity (RH) rise due to Western Disturbances rains and other RH rise events in the first wave $-2^{\text {nd }}$ Peak of 2020

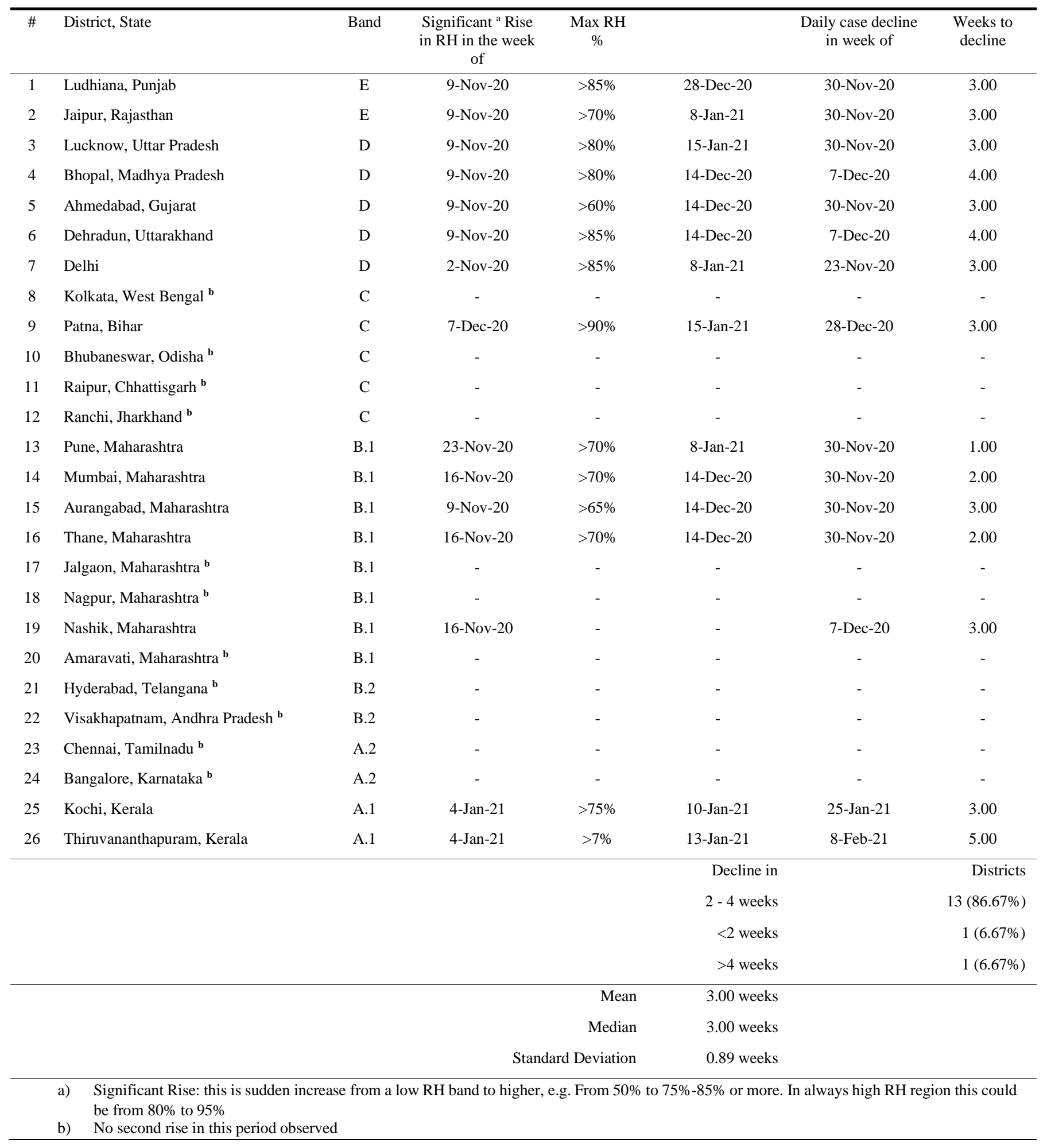

